\title{
Review Article \\ Perovskite Thin Film Solar Cells Based on Inorganic Hole Conducting Materials
}

\author{
Pan-Pan Zhang, ${ }^{1,2}$ Zheng-Ji Zhou, ${ }^{1,2}$ Dong-Xing Kou, ${ }^{1,2}$ and Si-Xin $\mathrm{Wu}^{1,2}$ \\ ${ }^{1}$ Key Laboratory for Special Functional Materials of Ministry of Education, Henan University, Kaifeng, \\ Henan Province 475004, China \\ ${ }^{2}$ Collaborative Innovation Center of Nano Functional Materials and Applications, Henan University, Kaifeng, \\ Henan Province 475004, China \\ Correspondence should be addressed to Zheng-Ji Zhou; zzj@henu.edu.cn
}

Received 13 October 2016; Revised 14 February 2017; Accepted 23 February 2017; Published 3 May 2017

Academic Editor: Wilfried G.J.H.M. Van Sark

Copyright @ 2017 Pan-Pan Zhang et al. This is an open access article distributed under the Creative Commons Attribution License, which permits unrestricted use, distribution, and reproduction in any medium, provided the original work is properly cited.

\begin{abstract}
Organic-inorganic metal halide perovskites have recently shown great potential for application, due to their advantages of low-cost, excellent photoelectric properties and high power conversion efficiency. Perovskite-based thin film solar cells have achieved a power conversion efficiency (PCE) of up to $20 \%$. Hole transport materials (HTMs) are one of the most important components of perovskite solar cells (PSCs), having functions of optimizing interface, adjusting the energy match, and helping to obtain higher PCE. Inorganic p-type semiconductors are alternative HTMs due to their chemical stability, higher mobility, high transparency in the visible region, and applicable valence band (VB) energy level. This review analyzed the advantages, disadvantages, and development prospects of several popular inorganic HTMs in PSCs.
\end{abstract}

\section{Introduction}

Perovskite solar cells (PSCs) based on organic-inorganic metal halide perovskites have recently attracted considerable attention as the power conversion efficiency (PCE) has increased dramatically from the initial 3.9\% in 2009 to current $22.1 \%$ in a short span of several years [1-8]. Previous results demonstrated that PSCs may be the first in the history of photovoltaics (PV) combining high efficiency with low cost. The configurations of PSCs were evolved from dyesensitized solar cells (DSSCs), and the key materials for the perovskite are compounds with the chemical formula $\mathrm{ABX}_{3}\left(\mathrm{~A}=\mathrm{CH}_{3} \mathrm{NH}_{3}, \mathrm{~B}=\mathrm{Pb}\right.$ or $\mathrm{Sn}$, and $\mathrm{X}=\mathrm{Cl}, \mathrm{Br}$, or $\left.\mathrm{I}\right)$, which have received extensive attention due to their favorable photovoltaic properties $[9,10]$. Generally, the device structure of PSCs can be categorized into mesoporous structure (Figure 1(a)) and planar junction structure (Figure 1(b)) [11]. The main function of perovskite is absorbing light to generate and transmit electron-hole pairs under continuous illumination. Then, the electrons and holes pass through the perovskite and shift to electron-transporting layer (ETL) and hole transport layer (HTL), respectively, to generate current, as schematic presented in Figure 1(c).

While although a mass of efforts such as solvent additives, molecular dipoles, or interface modification has been devoted to optimize device efficiency, none of the present PSCs provides high PCE with long-term stability. Undoubtedly, a lack of confirmed stability may become the biggest barrier on the path of PSCs towards commercialization. HTL is one of the most important components of PSCs, having functions of optimizing interface, adjusting the energy-match, and helping obtain higher PCE, which has a great effect on device performance and stability [12-14]. Poly(3,4-ethylenedioxythiophene)-polystyrenesulfonate (PEDOT:PSS) and 2,2',7,7'-tetrakis (N,N-di-p-methoxyphenylamine)-9,9,-spirobifluorene (spiro-OMeTAD) have been widely employed as HTL in the field of PSCs. Although PSCs that applied PEDOT:PSS and spiro-OMeTAD as HTL have obtained high PCE, none of them can provide with long-term stability partly because of the problematic acidic and hygroscopic characteristics of the organic HTMs applied in PSCs $[15,16]$. 


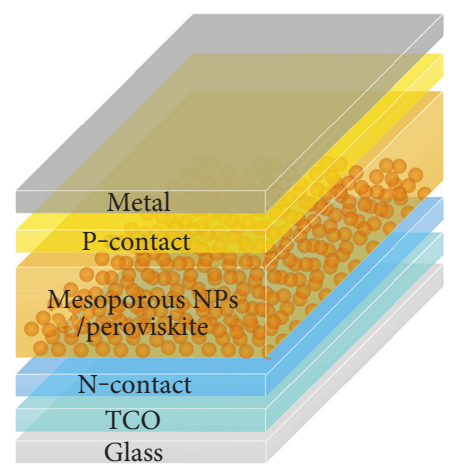

(a)

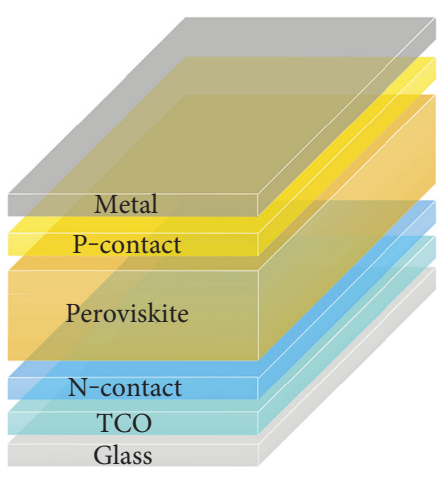

(b)

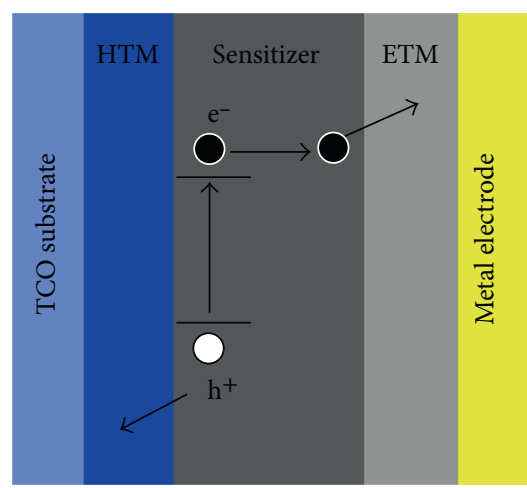

(c)

Figure 1: Device structures of (a) mesoporous structure, (b) n-i-p planar, planar junction structure, and (c) the scheme of carrier transport in PSCs.

TABLE 1: Device parameters for high-performance organometallic lead halide perovskite solar cells (PSCs) based on different inorganic hole transport materials (HTMs), the band gap, and deposition method of these HTMs.

\begin{tabular}{lccccccc}
\hline $\mathrm{HTM}$ & Band gap $(\mathrm{eV})$ & Deposition method & $V_{\mathrm{oc}}(\mathrm{V})$ & $J_{\text {sc }}\left(\mathrm{mA} / \mathrm{cm}^{2}\right)$ & FF $(\%)$ & PCE $(\%)$ & Reference \\
\hline $\mathrm{NiO}$ & 3.5 & ALD & 1.04 & 21.87 & 72 & 16.40 & {$[37]$} \\
$\mathrm{Cu}: \mathrm{NiO}$ & $x>3.5$ & Solution-processed & 1.12 & 19.17 & 73 & 15.40 & {$[24]$} \\
$\mathrm{Mg}: \mathrm{Li}: \mathrm{NiO}$ & $x>3.5$ & Solution-processed & 1.07 & 20.62 & 75 & 18.40 & {$[36]$} \\
$\mathrm{CuI}$ & 3.1 & Solution-processed & 1.04 & 21.06 & 62 & 13.58 & {$[40]$} \\
$\mathrm{CuSCN}$ & 3.8 & Electrodeposition & 1.00 & 21.90 & 76 & 16.60 & {$[46]$} \\
$\mathrm{CuO}$ & 1.3 & Solution-processed & 1.06 & 15.82 & 72 & 12.16 \\
$\mathrm{Cu}_{2} \mathrm{O}$ & 2.1 & Solution-processed & 1.07 & 16.52 & 75 & 13.35 \\
$\mathrm{MoO}_{3}$ & 3.4 & Thermal decomposition & 1.00 & 21.49 & 69 & 14.87 \\
$\mathrm{VO}_{x}$ & 2.42 & Solution-processed & 0.90 & 22.29 & 71 & {$[52]$} \\
\hline
\end{tabular}

Recently, to improve the stability and reduce the cost of PSCs, various inorganic hole transport materials have been discovered and applied. In this review, PSCs employing different inorganic HTMs as hole transport layer (HTL) have been discussed and summarized. To date, a series of p-type inorganic metal compounds have been employed in PSCs, such as $\mathrm{CuI}$ [17], CuSCN [18-20], $\mathrm{NiO}$ [21-26], $\mathrm{CuO}$ [27], $\mathrm{Cu}_{2} \mathrm{O}[27,28], \mathrm{MoO}_{3}$ [29-31], and $\mathrm{VO}_{x}$ [32]. Compared to organic HTMs, inorganic p-type semiconductor materials have the advantages of high hole mobility, wide band gap, low cost, and solution-processed availability, which show promising prospects as hole-selective contacts in perovskite solar cells.

\section{Inorganic HTMs for PSCs}

There are some general requirements for inorganic HTMs used in PSCs, such as high transparency in the visible region, well chemical stability, higher mobility, and applicable valence band (VB) energy level. At present, inorganic HTMs such as CuI, CuSCN, $\mathrm{NiO}, \mathrm{CuO}, \mathrm{Cu}_{2} \mathrm{O}, \mathrm{MoO}_{3}$, and $\mathrm{VO}_{x}$ have already been used in PSCs and the solar cells employing inorganic p-type semiconductors as HTLs exhibited improvement in device performance and stability.
Table 1 presents the band gap and deposition method of various HTMs reported in the literatures, as well as their photovoltaic parameters of top-performing PSCs based on these HTMs. In the following, we will analyze and discuss these frequently used inorganic HTMs, respectively.

2.1. $\mathrm{NiO}$. $\mathrm{NiO}$ is a well-known p-type semiconductor widely used as a p-sensitization electrode for DSSCs and a hole-selective contact for organic bulk heterojunction solar cells $[33,34]$.

Initially, $\mathrm{NiO}$ was widely applied in DSSCs. In recent years, nickel oxide (NiO) as a promising HTM has been studied by several groups. In 2014, the first announced PCE of PSCs using nickel oxide as HTL was up to 7.8\% [35]. Then, $\mathrm{NiO}$ nanocrystals (NCs) were obtained by a simple sol-gel process adopted as the hole transport layer in an inverted PSC, which observed a high PCE of 9.11\% [25]. In 2015, copper- $(\mathrm{Cu}-)$ doped $\mathrm{NiO}(\mathrm{Cu}: \mathrm{NiO})$ as $\mathrm{HTL}$ of planar heterojunction PSCs achieved a PCE of 15.4\% [24]. At present, the highest recorded PCE of PSCs using $\mathrm{Li}, \mathrm{Mg}$ codoped $\mathrm{NiO}\left(\mathrm{Li}_{0.05} \mathrm{Mg}_{0.15} \mathrm{Ni}_{0.8} \mathrm{O}\right)$ as $\mathrm{HTL}$ was $18.4 \%$ [36]. This study developed heavily $\mathrm{p}$-doped $\left(\mathrm{p}^{+}\right) \mathrm{Ni}_{x} \mathrm{Mg}_{1-x} \mathrm{O}$ to extract photogenerated hole from perovskite layer, and large size $\left(>1 \mathrm{~cm}^{2}\right)$ PSCs with an efficiency of up to $16.2 \%$ were 


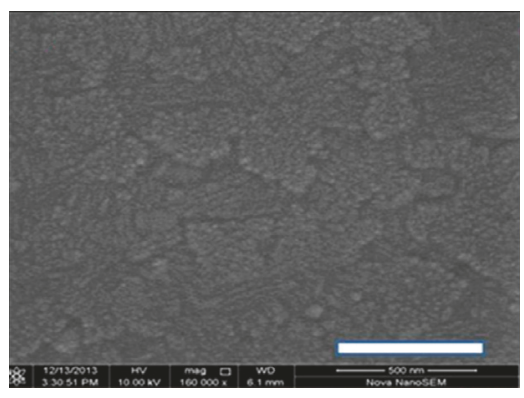

(a)

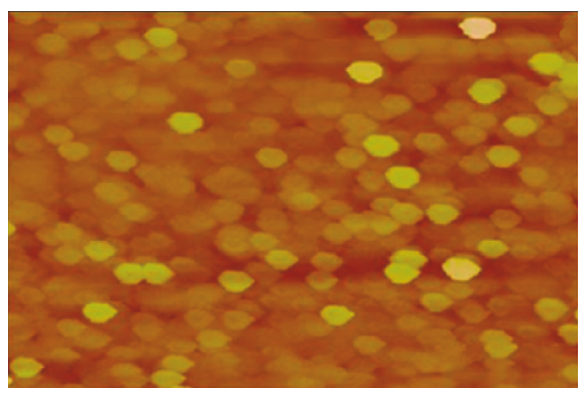

(b)

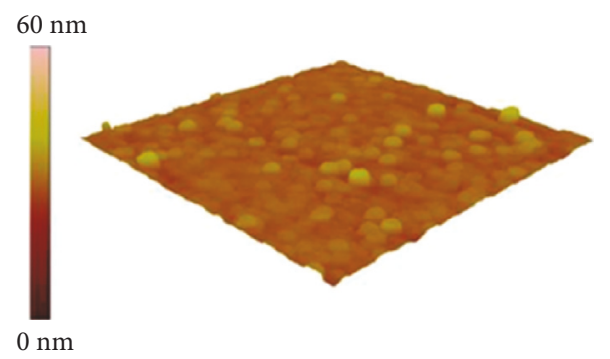

(c)

Figure 2: (a) SEM NiO film prepared by spin coating, (b) and (c) AFM of NiO film prepared by spin coating. Reprinted with permission from [21].

successfully fabricated. The latest reported PCE of PSCs employing pure $\mathrm{NiO}$ as $\mathrm{HTL}$ is up to $16.4 \%$, and the $\mathrm{NiO}$ film was gotten by the atomic layer deposition (ALD) method [37].

$\mathrm{NiO}$ become a potential candidate for HTL, as its p-type characteristics of high optical transmittance, wide band gap $(\mathrm{Eg}>3.50 \mathrm{eV})$, chemical stability, and an applicable valence band match with common light photoactive layers [33,38]. The synthetic methods of $\mathrm{NiO}$ can be categorized into solution-processed and sol-gel, and $\mathrm{NiO}$ films can be prepared by various methods, such as pulsed laser deposition, electrodeposition, spray pyrolysis, spin coating, sputtering, and ALD method [37]. A frequently used method for preparing $\mathrm{NiO}$ is solution-processed technique by adding monoethanolamine and nickel acetate tetrahydrate in methoxyethanol then stirring for 10 hours to form $\mathrm{NiO}$ precursor solutions and via spin coating to achieve $\mathrm{NiO}$ film. The $\mathrm{NiO}$ film obtained by this way was composed of $\mathrm{NiO}$ nanoparticles (NCs), and the whole film was crack-free and smooth, as schematic presented in SEM and AFM (Figures 2(a), 2(b), and 2(c)). The photoluminescence (PL) quenching of perovskite based on $\mathrm{NiO}$ showed favorable charge transfer compatibility, presented in Figure 3. Perovskite excitation is at around $760 \mathrm{~nm}$. Finally, PSC with $\mathrm{NiO}$ prepared by the above method as HTL obtained a 7.6\% device performance [21].

Another common approach to achieve $\mathrm{NiO}$ is a simple sol-gel process. $\mathrm{NiO}$ film was fabricated by spin coating the sol-gel solution. This kind of $\mathrm{NiO}$ nanocrystal film with a flat and smooth surface guarantees the formation of a continuous and close-knit HTLs of PSCs as schematic presented in Figures 4(a) and 4(b). Hole extraction and transport properties of this film interfaced with the perovskite film were

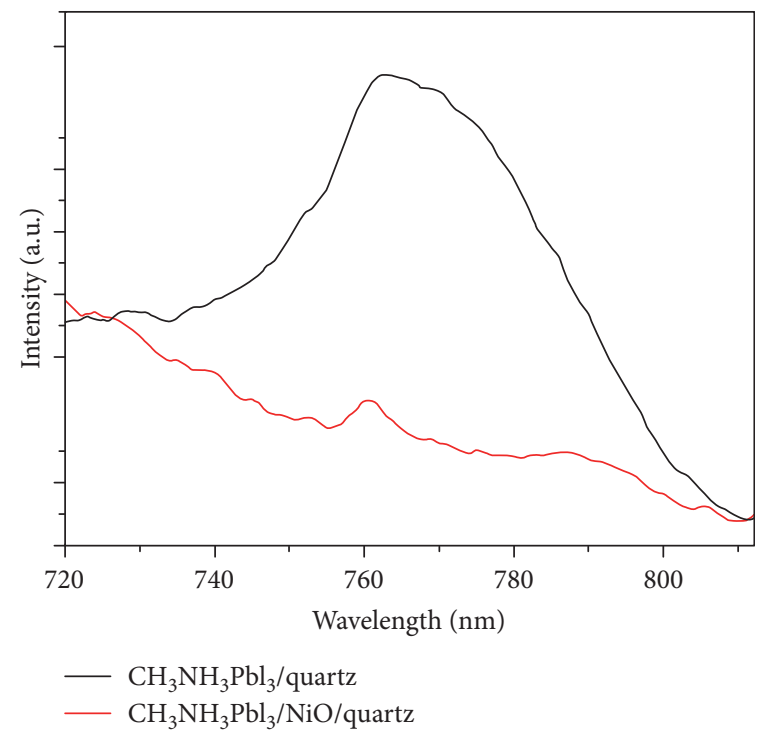

FIgURE 3: Photoluminescence spectra (excited by $600 \mathrm{~nm}$ laser) of $\mathrm{CH} 3 \mathrm{NH} 3 \mathrm{PbI} 3$ film deposited on top of $\mathrm{NiO}$ film or quartz substrate. Reprinted with permission from [21].

higher than those of organic HTLs, such as PEDOT:PSS, and perovskite deposited on $\mathrm{NiO} \mathrm{NC}$ films is with homogeneous phase. The PSCs with HTL of $\mathrm{NiO} \mathrm{NC}$ film at a thickness of around $35 \mathrm{~nm}$ exhibited the best PCE of 9.11\%, as showed in Figure 4(c) [25].

Recently, ALD method has been used to fabricate ultrathin pure un-doped $\mathrm{NiO}$ films. And PSCs employing this kind of NiO film as HTL achieved a high PCE of $16.4 \%$. We can fabricate highly sequential and dense ultrathin films at nanometer size following the ALD method. 


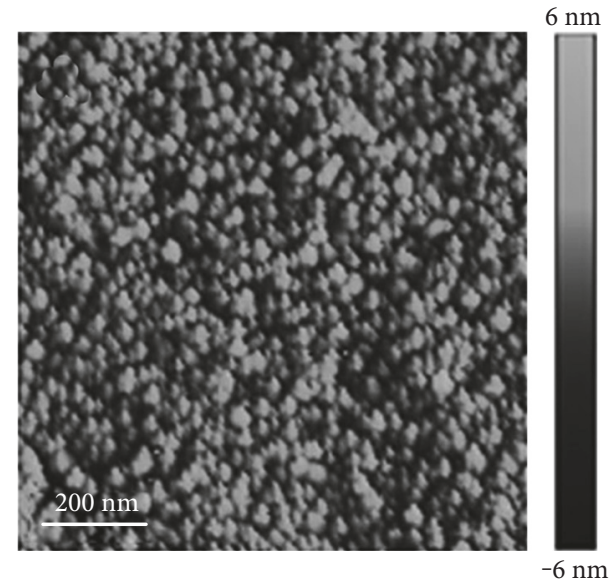

(a)

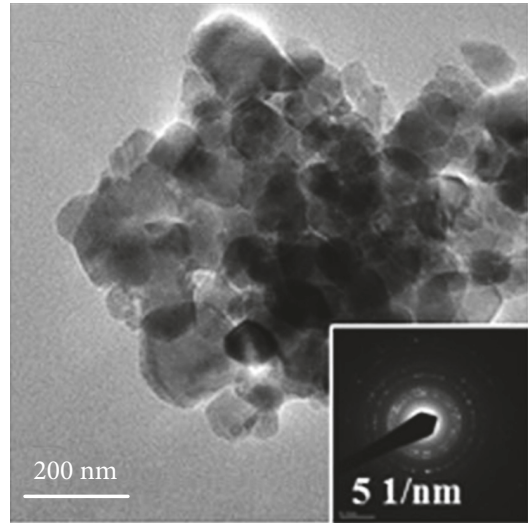

(b)

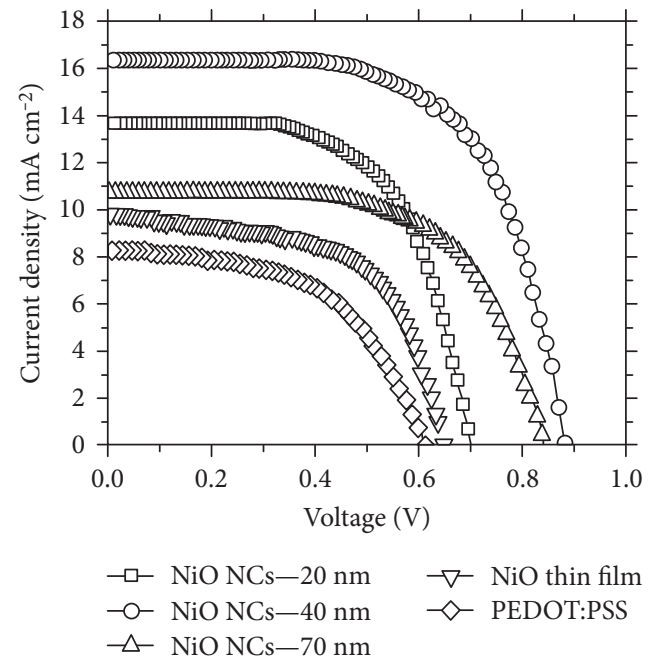

(c)

Figure 4: (a) AFM roughness image of a NiO nanocrystal film on FTO. (b) Bright-field TEM image of a sample of NiO NCs with the corresponding diffraction pattern (inset). (c) Typical J-V curves of the perovskite solar cells with different NiO hole transport layers and PEDOT:PSS. Reprinted with permission from [25].

The effective work function (WF) of ultrathin NiO apparently increased, which enormously promoted the hole extraction performance. In addition, ultrathin $\mathrm{NiO}$ films have a higher transparency which highly contribute to the photovoltaic devices. The freshly ultrathin pure undoped $\mathrm{NiO}$ films deposited as HTL of PSCs exhibited a high PCE of $16.4 \%$ with $J_{\mathrm{sc}}=21.9 \mathrm{~mA} \mathrm{~cm}^{-2}, V_{\mathrm{oc}}=1.04 \mathrm{~V}$, and $\mathrm{FF}=0.72$ [37].

A salient weakness with PSCs' use of $\mathrm{NiO}$ as HTL is that it is hard for $\mathrm{NiO}$ to support an ultrathin perovskite film $(<60 \mathrm{~nm})[22,23]$, which has still limited the development of PCE of PSCs using $\mathrm{NiO}$ as HTLs. Another shortage with PSCs employing $\mathrm{NiO}$ as HTL is that FF and $V_{\mathrm{oc}}$ are lower than the common organic HTMs, in particular when the $\mathrm{NiO}$ was achieved by the solution-processed method. These parameters greatly affect the device performance [37].

Briefly speaking, an ideal p-NiO film for high PV performance should (1) have high transparency, (2) have favorable hole extraction and transport performance properties,

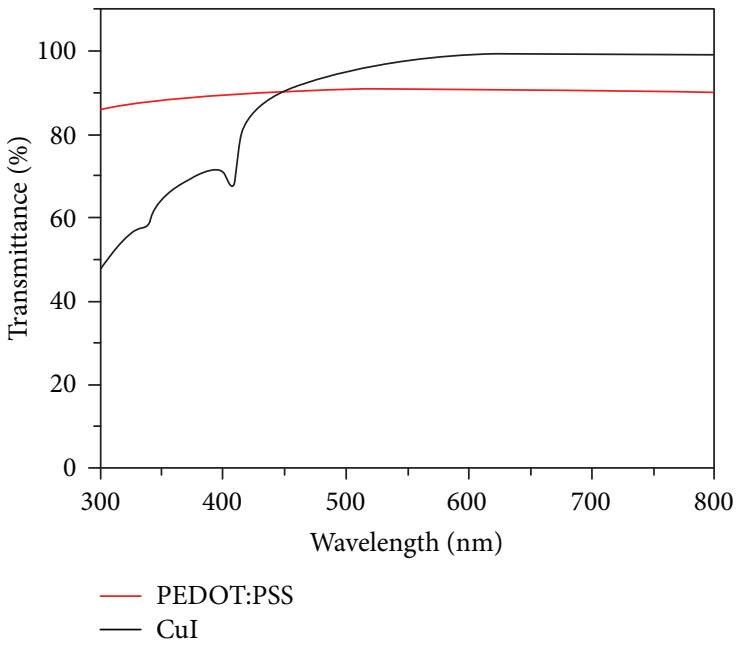

FIgure 5: Optical transmission spectra of the PEDOT:PSS film and CuI film. Reprinted with permission from [40]. 


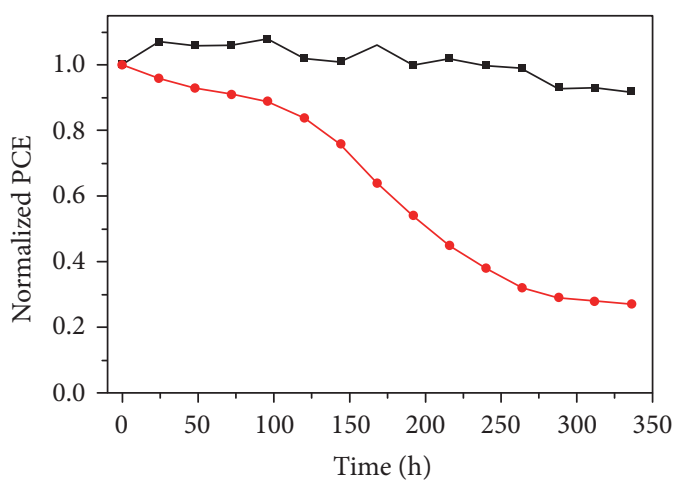

(a)

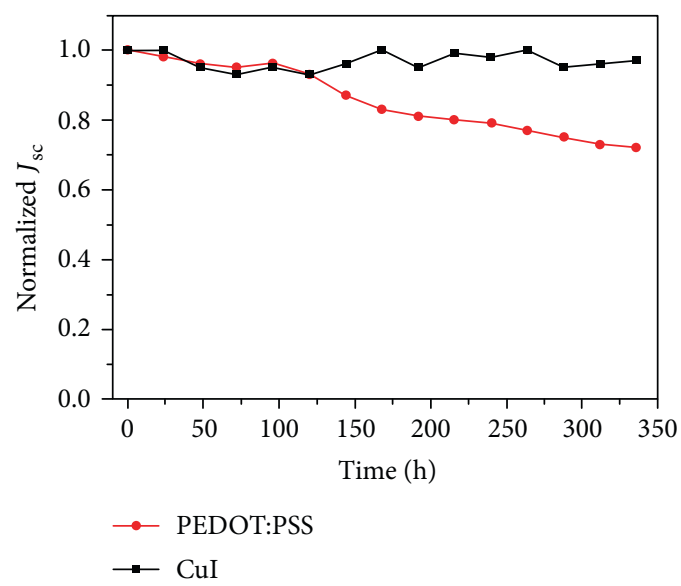

(c)

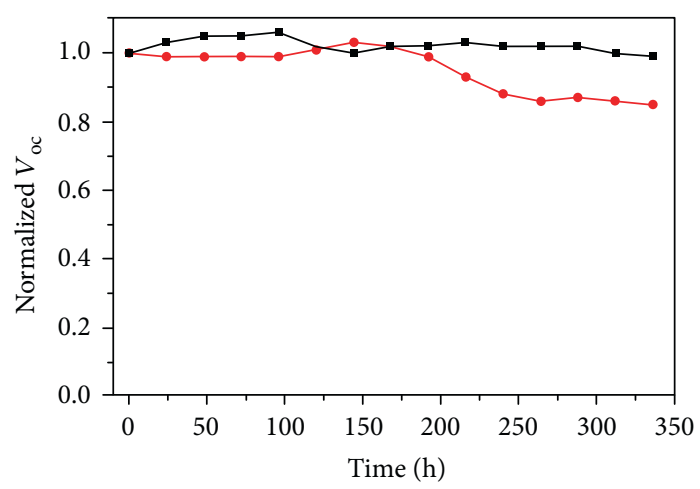

(b)

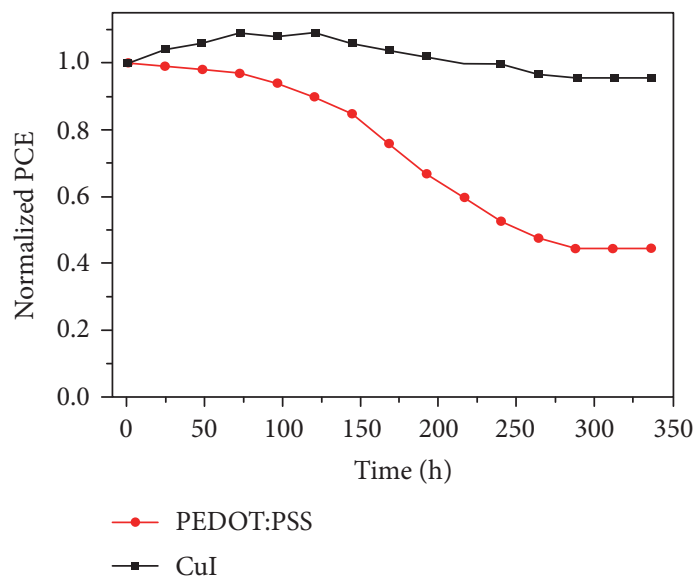

(d)

FIgure 6: Normalized PCE (a), $V_{\mathrm{oc}}(\mathrm{b}), J_{\mathrm{sc}}(\mathrm{c})$, and FF (d) of perovskite solar cells employing CuI and PEDOT:PSS HTLs as a function of storage time in air. Reprinted with permission from [40].

(3) have applicable energy levels, and (4) have low cost and easy access [33].

2.2. CuI. Inorganic p-type semiconductor copper iodide (CuI) becomes one of the promising HTLs for PSCs, due to its admirable properties such as wide band gap, high conductivity, low cost, and solution processable. At the beginning, $\mathrm{CuI}$ as hole conductors was employed in DSSCs and quantum dot-sensitized solar cells. In recent years, several groups have used CuI as HTLs for PSCs, and the first application of $\mathrm{CuI}$ for PSCs has successfully achieved a potential PCE of $6.0 \%$ [17]. Then, the PCE of PSCs using CuI as HTL increased to 7.5\% [39]. In 2015, the PCE of PSCs applying $\mathrm{CuI}$ as HTL in inverted planar heterojunction perovskite solar cells reach up to $13.8 \%$ [40]. At present, the highest announced PCE of PSCs using CuI as HTL is 16.8\% [41].

Solution-processed method is the frequently used approach to acquire $\mathrm{CuI}$. The $\mathrm{CuI}$ films were prepared by spin coating CuI precursor solution in inert gas. Compared to PEDOT:PSS, CuI films exhibit higher transmittance in visible light from 450 to $800 \mathrm{~nm}$ (Figure 5), which make it potential to be used as a HTL. In addition, high transparency can allow more photo flux reach perovskite active layer to generate intense photocurrent. However, the surface morphology of CuI films is rough when compared to PEDOT:PSS films, which may be because of the existence of large CuI grains [40].

At present, PSCs employing CuI as HTLs have achieved a relatively high PCE of $13.58 \%$ [40]. Above all, PSCs using $\mathrm{CuI}$ as the HTL exhibited improved air stability when compared to PSCs employing PEDOT:PSS as the HTL (Figure 6). In this respect, CuI is an excellent choice, because long-term stability of PSCs is of vital significance for practical applications [40].

Although PSCs using CuI as HTLs can replace conventional organic HTMs, the device open-circuit voltage $\left(V_{\mathrm{oc}}\right)$ is relatively low mainly because of a high recombination rate as determined by impedance spectroscopy. There are still numerous challenges in the optimization of PSC-employed $\mathrm{CuI}$ as HTLs. The primary problems include (1) how to control the surface morphology of CuI, (2) how to achieve favorable contacts between CuI layer and perovskite layer, and (3) how to dissolve $\mathrm{CuI}$ and eliminate large $\mathrm{CuI}$ grains.

2.3. CuSCN. As mentioned above, copper thiocyanate (CuSCN) appears to be a good candidate of inorganic HTLs for its internal p-type characteristics of a wide band gap and high optical transparency [42-44].

CuSCN was first applied in mesoporous PSCs by Ito et al. with a device structure of $\mathrm{FTO} / \mathrm{TiO}_{2} / \mathrm{TiO}_{2} / \mathrm{CH}_{3} \mathrm{NH}_{3} \mathrm{PbI}_{3} /$ 


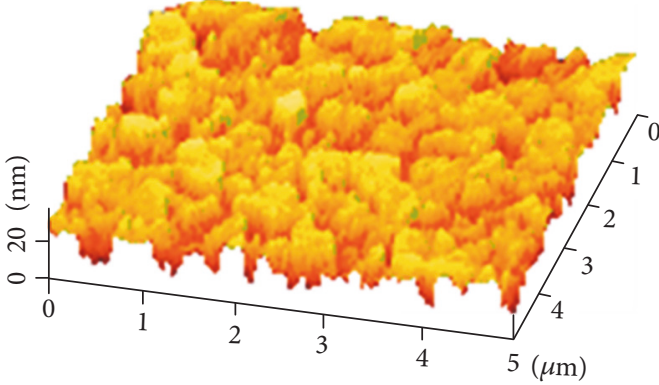

(a)

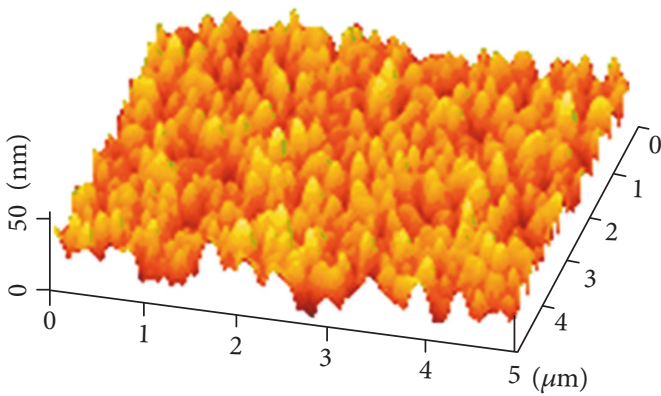

(c)

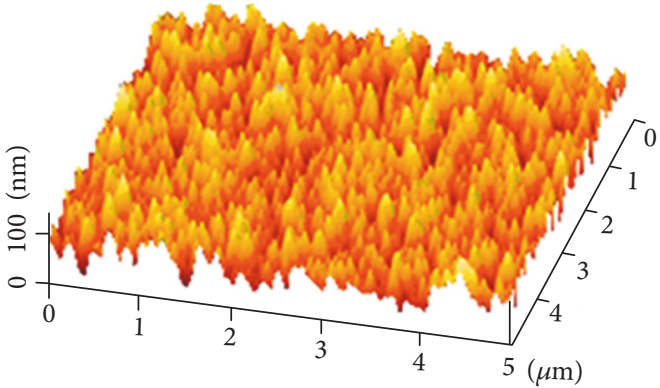

(b)

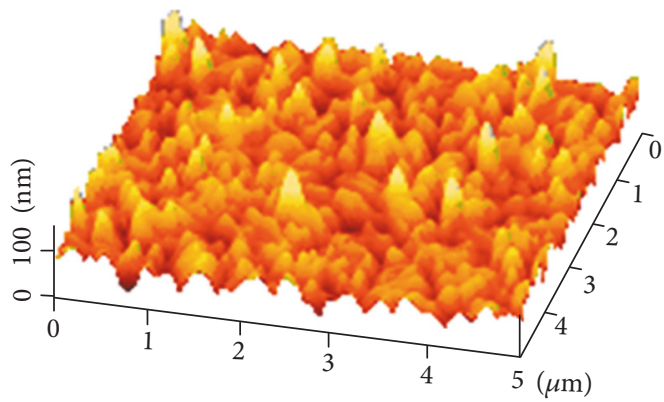

(d)

Figure 7: AFM images of ITO/glass (a), CuSCN/ITO/glass (b), $\mathrm{CH}_{3} \mathrm{NH}_{3} \mathrm{PbI}_{3}$ (one-step)/CuSCN/ITO/glass (c), and $\mathrm{CH}_{3} \mathrm{NH}_{3} \mathrm{PbI}_{3}$ (two-step)/ $\mathrm{CuSCN} / \mathrm{ITO} /$ glass (d). The RMS roughness values are 4.6, 19.3, 7.6, and $17.0 \mathrm{~nm}$, respectively. Reprinted with permission from [46].

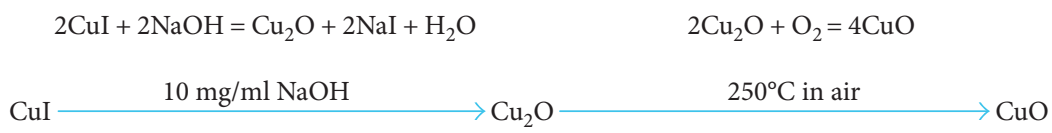

Figure 8: Preparation process for $\mathrm{Cu}_{2} \mathrm{O}$ and $\mathrm{CuO}$ films.

CuSCN/Au and achieved a PCE of $4.85 \%$ in 2013 [18]. Soon after, planar PSCs using CuSCN as a HTL received a PCE of 6.4\%. There were reported low PCEs of PSCs based on $\mathrm{CuSCN}$ mainly because of the poor quality of $\mathrm{CH}_{3} \mathrm{NH}_{3} \mathrm{PbI}_{3}$ active layer films on top of the CuSCN layers. Grätzel et al. enhanced the device PCE to $12.4 \%$ [45], via optimizing perovskite surface morphology by two times of iodide deposition. Then, the PCE of the CuSCN-based PSCs has already been improved to $16.6 \%[46,47]$. The latest announced PCE of PSCs using CuI as HTL has reached up to $18 \%$ [48]. In spite of the relatively low PCE compared to efficiency of PSCs based on organic HTMs, the low cost and air stability of CuSCN make it become a promising inorganic HTM.

The high PCE (16.6\%) photovoltaic device used a onestep fast deposition method to fabricate high-quality perovskite films based on a rough $\mathrm{CuSCN}$. $\mathrm{CH}_{3} \mathrm{NH}_{3} \mathrm{PbI}_{3}$ prepared by a one-step faster deposition method with lower surface roughness and smaller interface contact resistance was compared to the perovskite films prepared by a conventional two-step deposition process, as showed in Figure $7[46,49]$.

Although cells using CuSCN as HTL have achieved considerable device efficiency, the CuSCN layer was fabricated via electrodeposition, which needs to be carefully compounded from a precursor solution containing potassium thiocyanate $(\mathrm{KSCN})$, copper sulfate $\left(\mathrm{CuSO}_{4}\right)$, and ethylenediaminetetraacetic acid (EDTA). And the CuSCN films achieved by the above method are relatively rough and unshaped, which affect further improvements of PSCs [46].

2.4. $\mathrm{Cu}_{2} \mathrm{O}$ and $\mathrm{CuO}$. $\mathrm{CuO}$ and $\mathrm{Cu}_{2} \mathrm{O}$ are well-known p-type semiconductors $[27,28,50]$. There is a simple lowtemperature method to synthesize $\mathrm{Cu}_{2} \mathrm{O}$ and $\mathrm{CuO}$ films and employ them as HTL for PSCs. Traditional methods for preparing $\mathrm{Cu}_{2} \mathrm{O}$ film are thermal oxidation, sputtering, electrodeposition, and metal-organic chemical vapor deposition [51]. $\mathrm{Cu}_{2} \mathrm{O}$ film can be obtained via in situ conversion of $\mathrm{CuI}$ film in aqueous $\mathrm{NaOH}$ solution, and $\mathrm{CuO}$ film is fabricated by heating $\mathrm{Cu}_{2} \mathrm{O}$ film in the air, as showed in Figure 8 [52].

PSCs using $\mathrm{Cu}_{2} \mathrm{O}$ and $\mathrm{CuO}$ as HTMs show observably increased $V_{\mathrm{oc}}, J_{\mathrm{sc}}$, and PCE. Recently, PSCs using $\mathrm{Cu}_{2} \mathrm{O}$ and $\mathrm{CuO}$ as HTLs exhibited PCE of $13.35 \%$ and $12.16 \%$, respectively [52]. Additionally, $\mathrm{NH}_{4} \mathrm{Cl}$ was added into $\mathrm{CH}_{3} \mathrm{NH}_{3} \mathrm{PbI}_{3}$ precursor to improve crystallinity of perovskite in $\mathrm{Li}$ et al. study. The increased $V_{\text {oc }}$ mainly owns the $\mathrm{VB}$ of $\mathrm{Cu}_{2} \mathrm{O}$ and $\mathrm{CuO}$ well matching with $\mathrm{VB}$ of the 


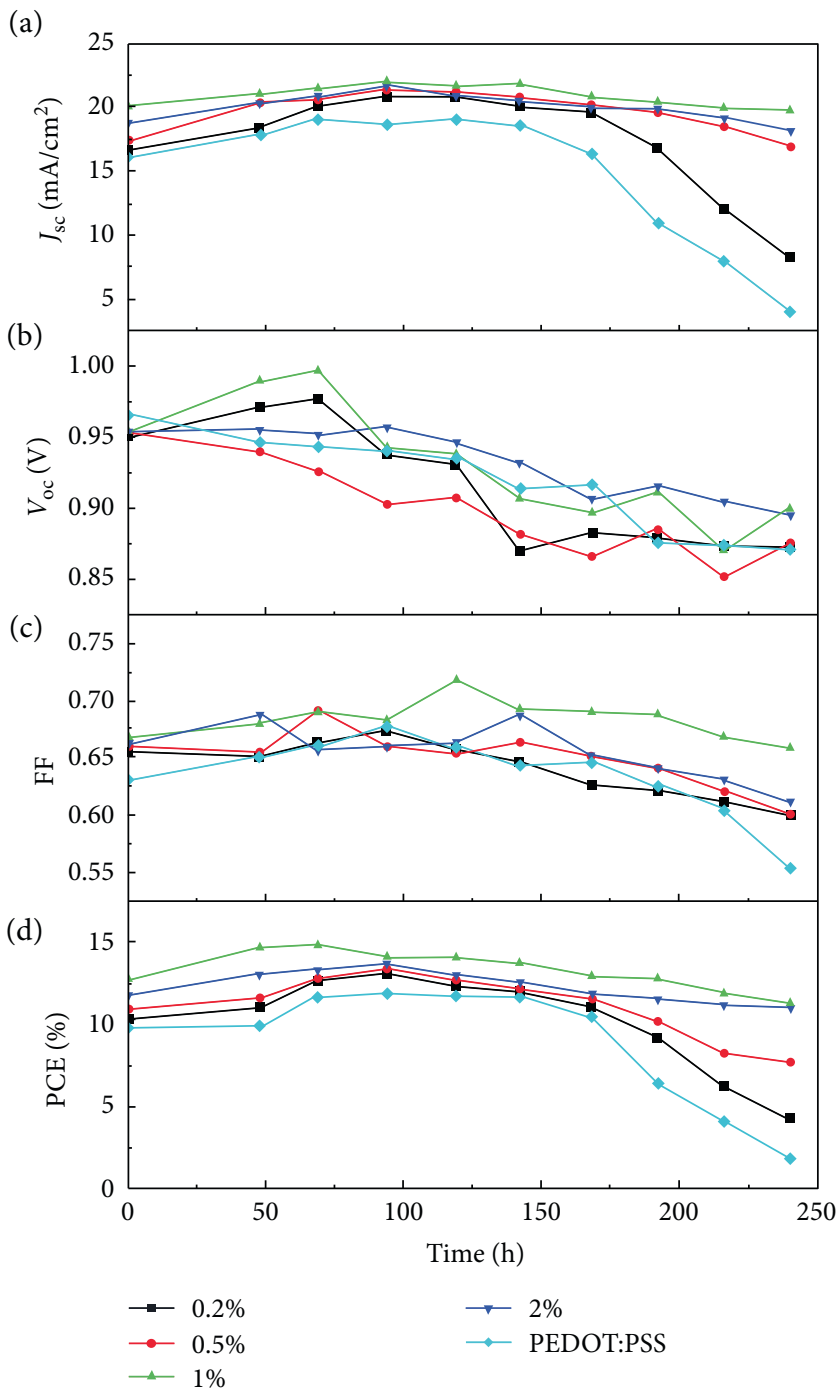

FIgure 9: (a) $J_{\text {sc }}$, (b) $V_{\text {oc }}$, (c) FF, and (d) PCE values as a function of aging time of the devices with different MoO $_{3} /$ PEDOT:PSS and pristine PEDOT:PSS HTLs. Reprinted with permission from [53].

perovskite and favorable crystallinity of perovskite on $\mathrm{Cu}_{2} \mathrm{O}$ and $\mathrm{CuO}$. What is more, well crystallinity enhanced the charge carrier transport and increased $J_{\text {sc }}$.

Compared to the PSCs employing $\mathrm{NiO}$ or $\mathrm{Cu}: \mathrm{NiO}$ as HTLs, $\mathrm{Cu}_{2} \mathrm{O}$-based cells showed a superior property due to the higher mobility of $\mathrm{Cu}_{2} \mathrm{O}$, less energy loss, and favorable perovskite surface morphology on $\mathrm{Cu}_{2} \mathrm{O}$ film [21]

2.5. $\mathrm{MoO}_{3} \cdot \mathrm{MoO}_{3}$ is another potential HTM owing to the advantage of nontoxicity and air stability. However, PSCs with $\mathrm{MoO}_{3}$ as HTL exhibit a low PCE mainly because of the poor quality of perovskite films deposited on $\mathrm{MoO}_{3}[29,31]$.

$\mathrm{MoO}_{3}$ is a good HTM, but the poor perovskite films deposited on top of it limit further improvement. In order to solve the difficult problem, one simple solution would be to use an $\mathrm{MoO}_{3} / \mathrm{PEDOT}$ :PSS composite film as the HTL in PSCs to take advantage of the ambient condition stability and favorable photovoltaic properties of $\mathrm{MoO}_{3}$ and at the same time guarantee the admirable surface morphology of perovskite film [53].
$\mathrm{Li}$ et al. used a $\mathrm{MoO}_{3} /$ PEDOT:PSS bilayer structure as the HTL for PSCs. $\mathrm{MoO}_{3}$ was prepared by a thermal decomposition of ammonium heptamolybdate $\left(\left(\mathrm{NH}_{4}\right)_{6} \mathrm{Mo}_{7} \mathrm{O}_{24}-\right.$ $4 \mathrm{H}_{2} \mathrm{O}$ ) solution at $80^{\circ} \mathrm{C}$. The PSCs have a structure of ITO/ $\mathrm{MoO}_{3} / \mathrm{PEDOT}: \mathrm{PSS} / \mathrm{CH}_{3} \mathrm{NH}_{3} \mathrm{PbI}_{3} / \mathrm{C} 60 /$ Bphen/Ag. The application of an $\mathrm{MoO}_{3}$ layer between ITO and PEDOT:PSS not only enhanced the hole extraction efficiency from perovskite to the ITO electrode but also avoided direct contact between rough $\mathrm{MoO}_{3}$ and $\mathrm{CH} 3 \mathrm{NH} 3 \mathrm{PbI}_{3}$. By this way, we can obtain a high-quality perovskite films deposited on top of PEDOT:PSS. These improvements contribute to the increase of stability and PCE of PSCs compared to the cells employing only PEDOT:PSS. Finally, the optimized PSCs exhibit a PCE of $14.87 \%$ [53]. What is more, the device stability increases when a $\mathrm{MoO}_{3}$ layer is inserted between ITO and PEDOT:PSS as showed in Figure 9 [53].

2.6. $V O_{x} \cdot \mathrm{VO}_{x}$ has become a favorable p-type semiconductor material primarily due to its higher work function (WF) and stability, and it can be prepared by low-temperature 


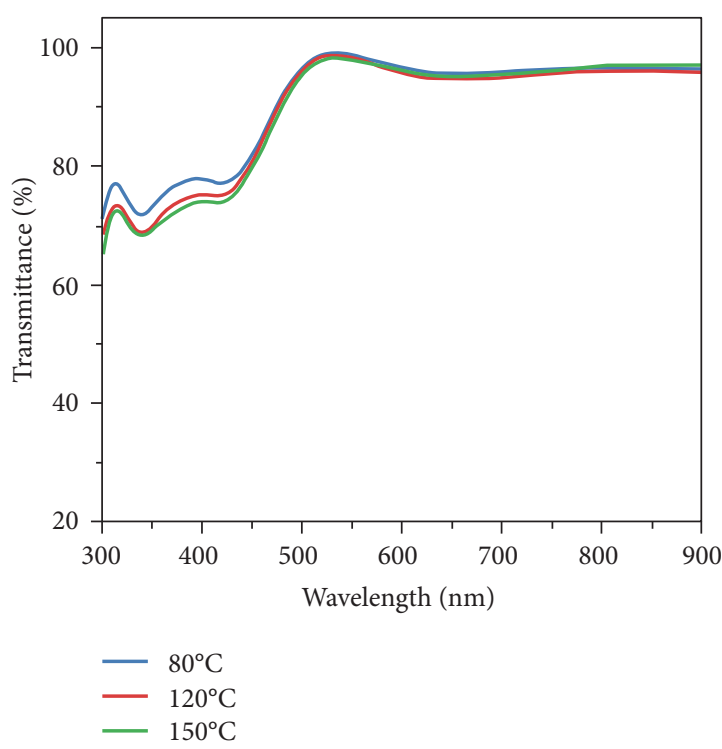

(a)

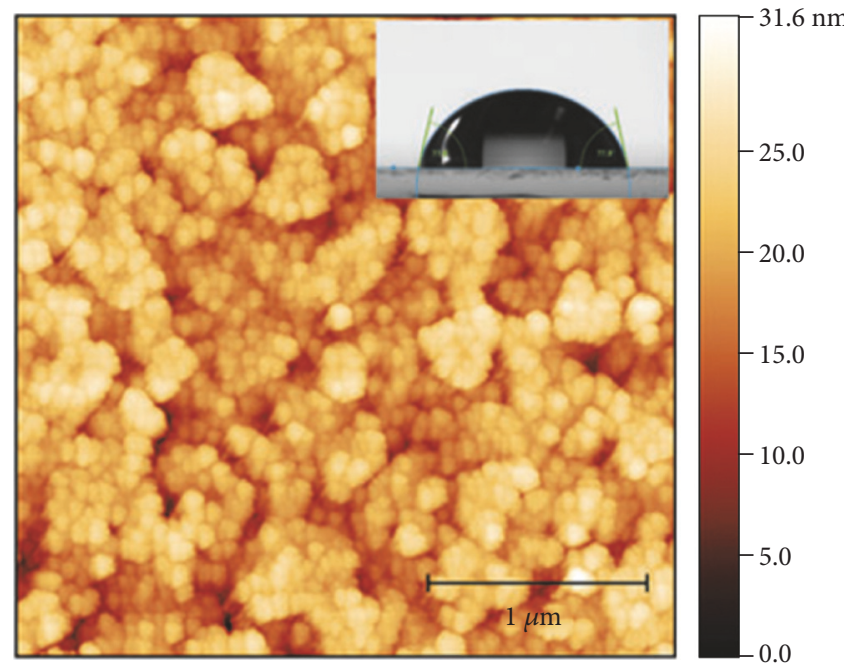

(c)

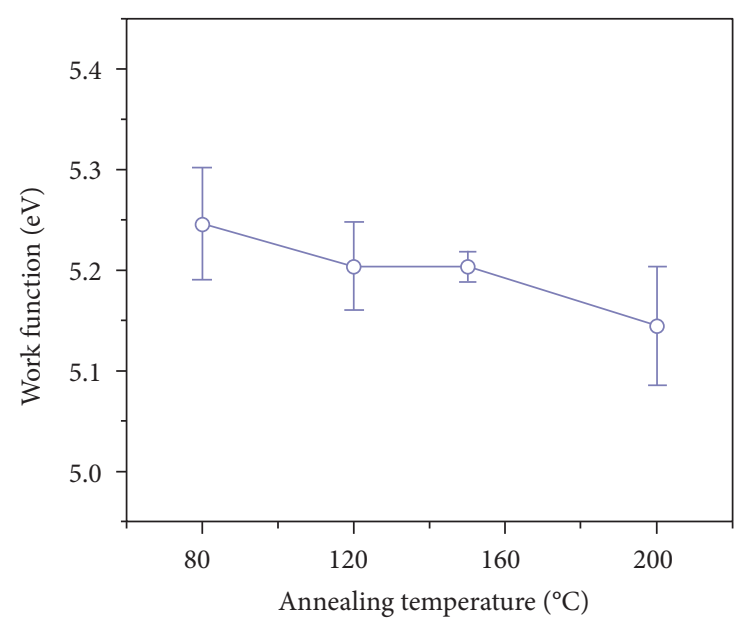

(b)

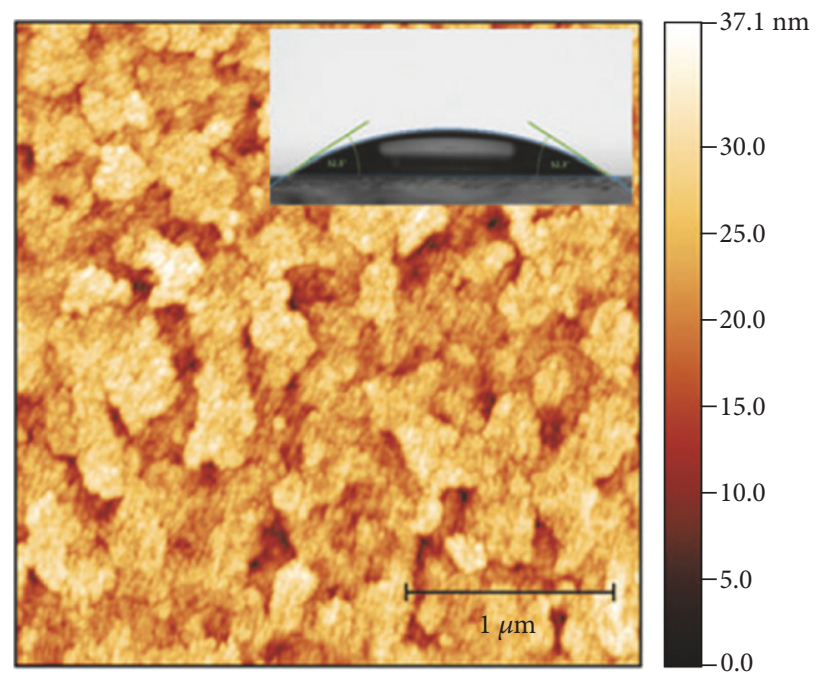

(d)

FIgURE 10: (a) Transmittance spectra of $V \mathrm{O}_{x}$ layers annealed at different temperatures. (b) Work function of $\mathrm{VO}_{x}$ layers annealed at different temperatures on ITO substrates. (c) AFM images of a bare ITO substrate. (d) AFM images of a $\mathrm{VO}_{x}$-coated ITO substrate. Reprinted with permission from [55].

solution-processed method $[32,54]$. At the beginning, $\mathrm{VO}_{x}$ was used as HTL in organic solar cells (OSCs). Recently, $\mathrm{VO}_{x}$ occurred as HTL for PSCs and achieved a relatively high PCE of $14.23 \%$ [55].

In general, $\mathrm{VO}_{x}$ films are fabricated by spin coating and annealed sol-gel precursor solution of $\mathrm{VO}_{x}$. And the measurements of the $\mathrm{VO}_{x}$ layer exhibit high transmittance and well-quenching efficiency (Figure 10(a)). The value of $x$ in $\mathrm{VO}_{x}$ was calculated at about 2.428 via $\mathrm{X}$-ray photoelectron spectroscopy (XPS). High WF (Figure 10(b)) of $\mathrm{VO}_{x}$ not only extremely benefits cells containing high ionization potential donor materials but also reduces losses in $V_{\text {oc }}$ and series resistance (Rs) [55]. However, $\mathrm{VO}_{x}$ is still faulty for it poor surface morphology result in harsh deposition of perovskite films, as showed in Figures 10(c) and $10(d)[24,45]$.

\section{Conclusion}

Inorganic semiconductor materials can be employed as hole-selective materials for PSCs due to their advantages of high hole mobility, wide band gap, and low cost, and they could be obtained by solution-processed method, showing promising respect of inorganic HTMs. What is more, the application of inorganic HTMs can enormously increase the stability and reduce cost of cells, which is very significant for PSCs. However, the reported device performance of most of the inorganic hole conductor-based PSCs 
is still much lower than that of cells with organic HTMs, which may result in the poor quality of perovskite films on top of the inorganic HTL.

\section{Conflicts of Interest}

The authors declare that there is no conflict of interest regarding the publication of this paper.

\section{Acknowledgments}

The authors would like to thank the National Natural Science Foundation of China (21271064 and 61306016), China Postdoctoral Science Foundation (2015M582179), and The Program for Changjiang Scholars and Innovative Research Team in the University (PCS IRT1126) of Henan University.

\section{References}

[1] A. Kojima, K. Teshima, Y. Shirai, and T. Miyasaka, "Organometal halide perovskites as visible-light sensitizers for photovoltaic cells," Journal of the American Chemical Society, vol. 131, no. 17, pp. 6050-6051, 2009.

[2] H. Zhou, Q. Chen, G. Li et al., "Interface engineering of highly efficient perovskite solar cells," Science, vol. 345, no. 6196, pp. 542-546, 2014.

[3] W. S. Yang, J. H. Noh, N. J. Jeon et al., "High-performance photovoltaic perovskite layers fabricated through intramolecular exchange," Science, vol. 348, no. 6240, pp. 1234-1237, 2015.

[4] N. J. Jeon, J. H. Noh, W. S. Yang et al., "Compositional engineering of perovskite materials for high-performance solar cells," Nature, vol. 517, no. 7535, pp. 476-480, 2015.

[5] Z. Yu and L. Sun, "Recent progress on hole-transporting materials for emerging organometal halide perovskite solar cells," Advanced Energy Materials, vol. 5, no. 12, 2015.

[6] S. Albrecht, M. Saliba, J. P. Baena et al., "Monolithic perovskite/ silicon-heterojunction tandem solar cells processed at low temperature," Energy \& Environmental Science, vol. 9, no. 1, pp. 81-88, 2016.

[7] H. S. Jung and N.-G. Park, "Perovskite solar cells: from materials to devices," Small, vol. 11, no. 1, pp. 10-25, 2015.

[8] "NREL efficiency chart," June 2016, http://www.nrel.gov/ ncpv/images/efficiency_chart.jpg.

[9] G. Chen, J. Seo, C. Yang, and P. N. Prasad, "Nanochemistry and nanomaterials for photovoltaics," Chemical Society Reviews, vol. 42, no. 21, pp. 8304-8338, 2013.

[10] M. A. Green, A. Ho-Baillie, and H. J. Snaith, "The emergence of perovskite solar cells," Nature Photonics, vol. 8, no. 7, pp. 560-514, 2014.

[11] M.-H. Li, P.-S. Shen, K.-C. Wang, T. F. Guo, and P. Chen, "Inorganic p-type contact materials for perovskite-based solar cells," Journal of Materials Chemistry A, vol. 3, no. 17, pp. 9011-9019, 2015.

[12] W. Yan, S. Ye, Y. Li et al., "Hole-transporting materials in inverted planar perovskite solar cells," Advanced Energy Materials, vol. 6, no. 17, 2016.

[13] T. Leijtens, G. E. Eperon, N. K. Noel, S. N. Habisreutinger, A. Petrozza, and H. J. Snaith, "Stability of metal halide perovskite solar cells," Advanced Energy Materials, vol. 5, no. 20, article 1500963, 2015.
[14] Y. Rong, L. Liu, A. Mei, X. Li, and H. Han, "Beyond efficiency: the challenge of stability in mesoscopic perovskite solar cells," Advanced Energy Materials, vol. 5, no. 20, article 1501066, 2015.

[15] J. Liu, Y. Wu, C. Qin et al., "A dopant-free holetransporting material for efficient and stable perovskite solar cells," Energy \& Environmental Science, vol. 7, no. 9, pp. 2963-2967, 2014.

[16] J. You, L. Meng, T.-B. Song et al., "Improved air stability of perovskite solar cells via solution-processed metal oxide transport layers," Nature Nanotechnology, vol. 11, no. 1, pp. 75-81, 2016.

[17] J. A. Christians, R. C. M. Fung, and P. V. Kamat, “An inorganic hole conductor for organo-lead halide perovskite solar cells. Improved hole conductivity with copper iodide," Journal of the American Chemical Society, vol. 136, no. 2, pp. 758-764, 2014.

[18] S. Ito, S. Tanaka, H. Vahlman, H. Nishino, K. Manabe, and P. Lund, "Carbon-double-bond-free printed solar cells from $\mathrm{TiO}_{2} / \mathrm{CH}_{3} \mathrm{NH}_{3} \mathrm{PbI}_{3} / \mathrm{CuSCN} / \mathrm{au}$ : structural control and photoaging effects," ChemPhysChem, vol. 15, no. 6, pp. 11941200, 2014.

[19] A. S. Subbiah, A. Halder, S. Ghosh, N. Mahuli, G. Hodes, and S. K. Sarkar, "Inorganic hole conducting layers for perovskitebased solar cells," Journal of Physcal Chemistry Letters, vol. 5, no. 10, pp. 1748-1753, 2014.

[20] S. Ito, S. Tanaka, K. Manabe, and H. Nishino, "Effects of surface blocking layer of $\mathrm{Sb}_{2} \mathrm{~S}_{3}$ on nanocrystalline $\mathrm{TiO}_{2}$ for $\mathrm{CH}_{3} \mathrm{NH}_{3} \mathrm{PbI}_{3}$ perovskite solar cells," The Journal of Physical Chemistry C, vol. 118, no. 30, pp. 16995-17000, 2014.

[21] L. Hu, J. Peng, W. Wang et al., "Sequential deposition of $\mathrm{CH}_{3} \mathrm{NH}_{3} \mathrm{PbI}_{3}$ on planar $\mathrm{NiO}$ film for efficient planar perovskite solar cells," ACS Photonics, vol. 1, no. 7, pp. 547-553, 2014.

[22] X. Yin, Z. Yao, Q. Luo et al., "High Efficiency Inverted Planar Perovskite Solar Cells with Solution-Processed NiOx Hole Contact," ACS Applied Materials \& Interfaces, vol. 9, no. 3, pp. 2439-2448, 2017.

[23] H. Tian, B. Xu, H. Chen, E. M. J. Johansson, and G. Boschloo, "Solid-state perovskite-sensitized p-type mesoporous nickel oxide solar cells," ChemSusChem, vol. 7, no. 8, pp. 2150-2153, 2014.

[24] J. H. Kim, P.-W. Liang, S. T. Williams et al., "Highperformance and environmentally stable planar heterojunction perovskite solar cells based on a solution-processed copper-doped nickel oxide hole-transporting layer," Advanced Materials, vol. 27, no. 4, pp. 695-701, 2015.

[25] Z. Zhu, Y. Bai, T. Zhang et al., "High-performance holeextraction layer of sol-gel-processed $\mathrm{NiO}$ nanocrystals for inverted planar perovskite solar cells," Angewandte Chemie, vol. 126, no. 46, pp. 12779-12783, 2014.

[26] W. Chen, Y. Wu, J. Liu et al., "Hybrid interfacial layer leads to solid performance improvement of inverted perovskite solar cells," Energy \& Environmental Science, vol. 8, no. 2, pp. 629-640, 2015.

[27] L. C. Chen, C. C. Chen, K. C. Liang et al., "Nano-structured $\mathrm{CuO}-\mathrm{Cu}_{2} \mathrm{O}$ complex thin film for application in $\mathrm{CH}_{3} \mathrm{NH}_{3} \mathrm{PbI}_{3}$ perovskite solar cells," Nanoscale Research Letters, vol. 11, no. 1, p. 402, 2016.

[28] S. Chatterjee and A. J. Pal, "Introducing $\mathrm{Cu}_{2} \mathrm{O}$ thin films as a hole-transport layer in efficient planar perovskite solar cell structures," Journal of Physical Chemistry C, vol. 120, no. 3, pp. 1428-1437, 2016. 
[29] Y. Zhao, A. M. Nardes, and K. Zhu, "Effective hole extraction using $\mathrm{MoO}_{\mathrm{x}}-\mathrm{Al}$ contact in perovskite $\mathrm{CH}_{3} \mathrm{NH}_{3} \mathrm{PbI}_{3}$ solar cells," Applied Physics Letters, vol. 104, no. 21, p. 213906, 2014.

[30] C. Liu, Z. Su, W. Li et al., "Improved performance of perovskite solar cells with a $\mathrm{TiO} 2 / \mathrm{MoO} 3$ core/shell nanoparticles doped PEDOT:PSS hole-transporter," Organic Electronics, vol. 33, pp. 221-226, 2016.

[31] Z.-L. Tseng, L.-C. Chen, C.-H. Chiang, S. H. Chang, C. C. Chen, and C. G. Wu, "Efficient inverted-type perovskite solar cells using UV-ozone treated $\mathrm{MoO}_{\mathrm{x}}$ and $\mathrm{WO}_{\mathrm{x}}$ as hole transporting layers," Solar Energy, vol. 139, pp. 484-488, 2016.

[32] M. Xiao, M. Gao, F. Huang et al., "Efficient perovskite solar cells employing inorganic interlayers," ChemNanoMat, vol. 2, no. 3, pp. 182-188, 2016.

[33] L. Alibabaei, H. Luo, R. L. House, P. G. Hoertz, R. Lopez, and T. J. Meyer, "Applications of metal oxide materials in dye sensitized photoelectrosynthesis cells for making solar fuels: let the molecules do the work," Journal of Materials Chemistry $a$, vol. 1, no. 13, pp. 4133-4145, 2013.

[34] M. D. Irwin, B. Buchholz, A. W. Hains, R. P. H. Chang, and T. J. Marks, "p-type semiconducting nickel oxide as an efficiency-enhancing anode interfacial layer in polymer bulk-heterojunction solar cells," Proceedings of the National Academy of Sciences of the United States of America, vol. 105, no. 8, pp. 2783-2787, 2008.

[35] J.-Y. Jeng, K.-C. Chen, T.-Y. Chiang et al., "Nickel oxide electrode interlayer in $\mathrm{CH}_{3} \mathrm{NH}_{3} \mathrm{PbI}_{3}$ perovskite/PCBM planarheterojunction hybrid solar cells," Advanced Materials, vol. 26, no. 24, pp. 4107-4133, 2014.

[36] W. Chen, Y. Wu, Y. Yue et al., "Efficient and stable large-area perovskite solar cells with inorganic charge extraction layers," Science, vol. 350, no. 6263, pp. 944-948, 2015.

[37] S. Seo, I. J. Park, M. Kim et al., "An ultra-thin, un-doped NiO hole transporting layer of highly efficient (16.4\%) organicinorganic hybrid perovskite solar cells," Nanoscale, vol. 8, no. 22, pp. 11403-11412, 2016.

[38] K. X. Steirer, J. P. Chesin, N. E. Widjonarko et al., "Solution deposited $\mathrm{NiO}$ thin-films as hole transport layers in organic photovoltaics," Organic Electronics, vol. 11, no. 8, pp. 14141418, 2016.

[39] G. A. Sepalage, S. Meyer, A. Pascoe et al., "Copper(I) iodide as hole-conductor in planar perovskite solar cells: probing the origin of $J-V$ hysteresis," Advanced Functional Materials, vol. 25, no. 35, pp. 5650-5661, 2015.

[40] W.-Y. Chen, L.-L. Deng, S.-M. Dai et al., "Low-cost solutionprocessed copper iodide as an alternative to PEDOT:PSS hole transport layer for efficient and stable inverted planar heterojunction perovskite solar cells," Journal of Materials Chemistry A, vol. 3, no. 38, pp. 19353-19359, 2015.

[41] W. Sun, S. Ye, H. Rao et al., "Room-temperature and solution processed copper iodide as the hole transport layer for inverted planar perovskite solar cells," Nanoscale, vol. 8, no. 35, pp. 15954-15960, 2016.

[42] C. Chappaz-Gillot, S. Berson, R. Salazar et al., "Polymer solar cells with electrodeposited CuSCN nanowires as new efficient hole transporting layer," Solar Energy Materials and Solar Cells, vol. 120, pp. 163-167, 2014.

[43] B. Li, L. Wang, B. Kang, P. Wang, and Y. Qiu, "Review of recent progress in solid-state dye-sensitized solar cells," Solar Energy Materials and Solar Cells, vol. 90, no. 5, pp. 549-574, 2006.
[44] P. Pattanasattayavong, N. Yaacobi-Gross, K. Zhao et al., "Hole-transporting transistors and circuits based on the transparent inorganic semiconductor copper(I) thiocyanate $(\mathrm{CuSCN})$ processed from solution at room temperature," Advanced Materials, vol. 25, no. 10, pp. 1504-1509, 2013.

[45] P. Qin, S. Tanaka, S. Ito et al., "Inorganic hole conductor-based lead halide perovskite solar cells with $12.4 \%$ conversion efficiency," Nature Communications, vol. 5, article 3834, 2014.

[46] S. Ye, S. W. Sun, Y. Li et al., "CuSCN-based inverted planar perovskite solar cell with an average PCE of 15.6\%," Nano Letters, vol. 15, no. 6, pp. 3723-3728, 2015.

[47] V. E. Madhavan, I. Zimmermann, C. Roldan-Carmona et al., "Copper thiocyanate inorganic hole-transporting material for high-efficiency perovskite solar cells," ACS Energy Letters, vol. 1, no. 6, pp. 1112-1117, 2016.

[48] M. Jung, Y. C. Kim, N. J. Jeon et al., "Thermal stability of CuSCN hole conductor-based perovskite solar cells," ChemSusChem Communications, vol. 9, no. 18, pp. 2592-2596, 2016.

[49] P. Pattanasattayavong, G. O. Ngongang Ndjawa, K. Zhao et al., "Electric field-induced hole transport in copper(I) thiocyanate $(\mathrm{CuSCN})$ thin-films processed from solution at room temperature," Chemical Communications, vol. 49, no. 39, pp. 4154-4156, 2013.

[50] B. K. Meyer, A. Polity, D. Reppin et al., "Binary copper oxide semiconductors: from materials towards devices," Physica Status Solidi B, vol. 249, no. 8, pp. 1487-1509, 2012.

[51] L.-C. Chen, "Review of preparation and optoelectronic characteristics of $\mathrm{Cu}_{2} \mathrm{O}$-based solar cells with nanostructure," Materials Science in Semiconductor Processing, vol. 16, no. 5, pp. 1172-1185, 2013.

[52] C. Zuo and L. Ding, "Solution-processed $\mathrm{Cu}_{2} \mathrm{O}$ and $\mathrm{CuO}$ as hole transport materials for efficient perovskite solar cells," Small, vol. 11, no. 41, pp. 5528-5532, 2015.

[53] F. Hou, Z. Su, F. Jin et al., "Efficient and stable planar heterojunction perovskite solar cells with an $\mathrm{MoO}_{3} /$ PEDOT:PSS hole transporting layer," Nanoscale, vol. 7, no. 21, pp. 94279432, 2015.

[54] P. Li, C. Liang, Y. Zhang, F. Li, Y. Song, and G. Shao, "Polyethyleneimine High-Energy Hydrophilic Surface Interfacial Treatment toward Efficient and Stable Perovskite Solar Cells," ACS Applied Materials \& Interfaces, vol. 8, no. 47, pp. 3257432580, 2016.

[55] H. Sun, X. Hou, Q. Wei et al., "Low-temperature solutionprocessed p-type vanadium oxide for perovskite solar cells," Chemical Communications, vol. 52, no. 52, pp. 8099$8102,2016$. 

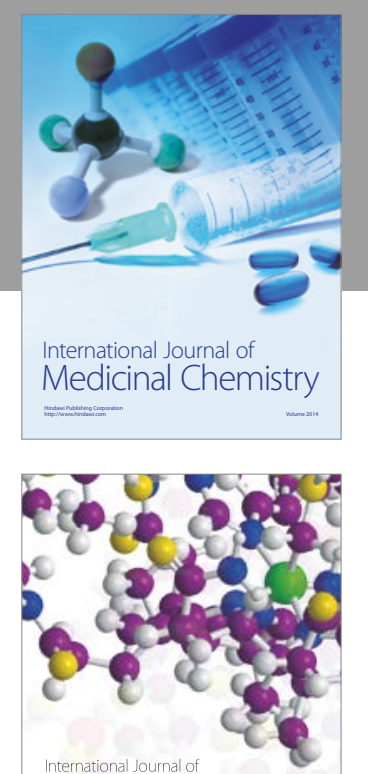

Carbohydrate Chemistry

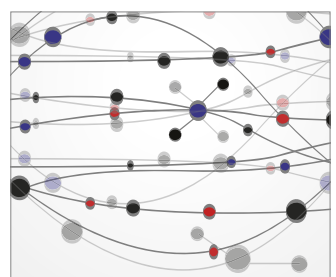

The Scientific World Journal
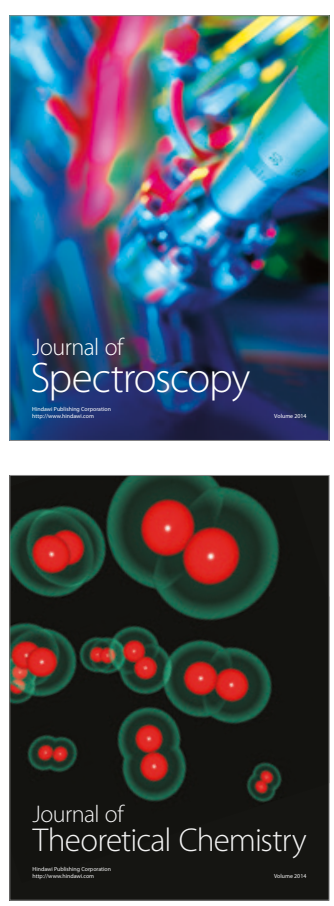
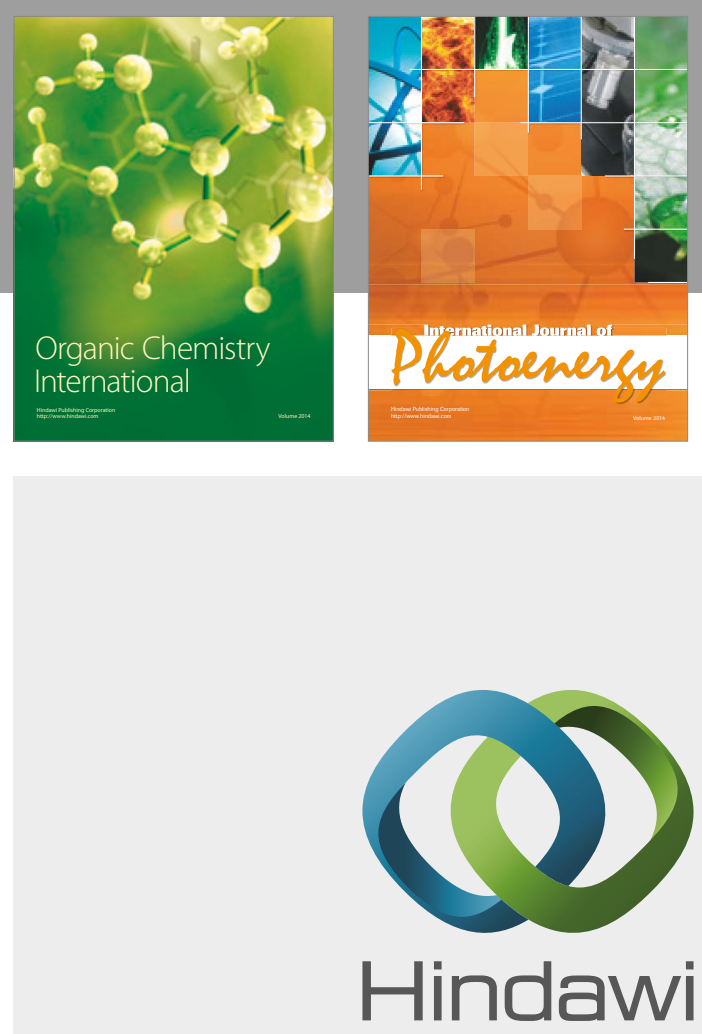

Submit your manuscripts at

https://www.hindawi.com

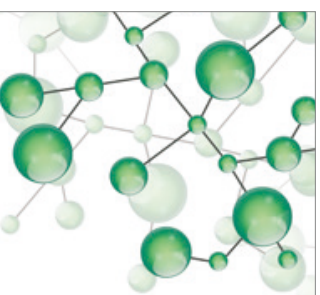

International Journal of

Inorganic Chemistry

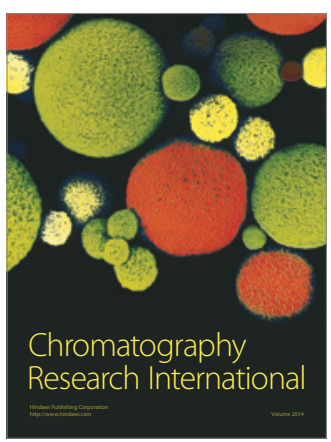

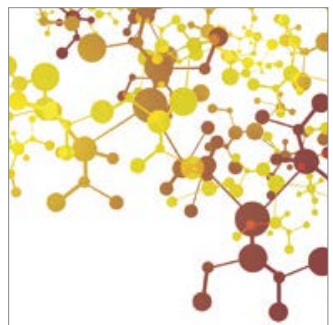

Applied Chemistry
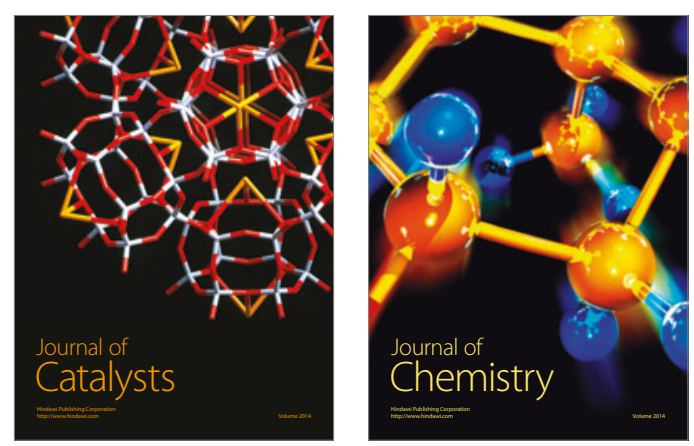
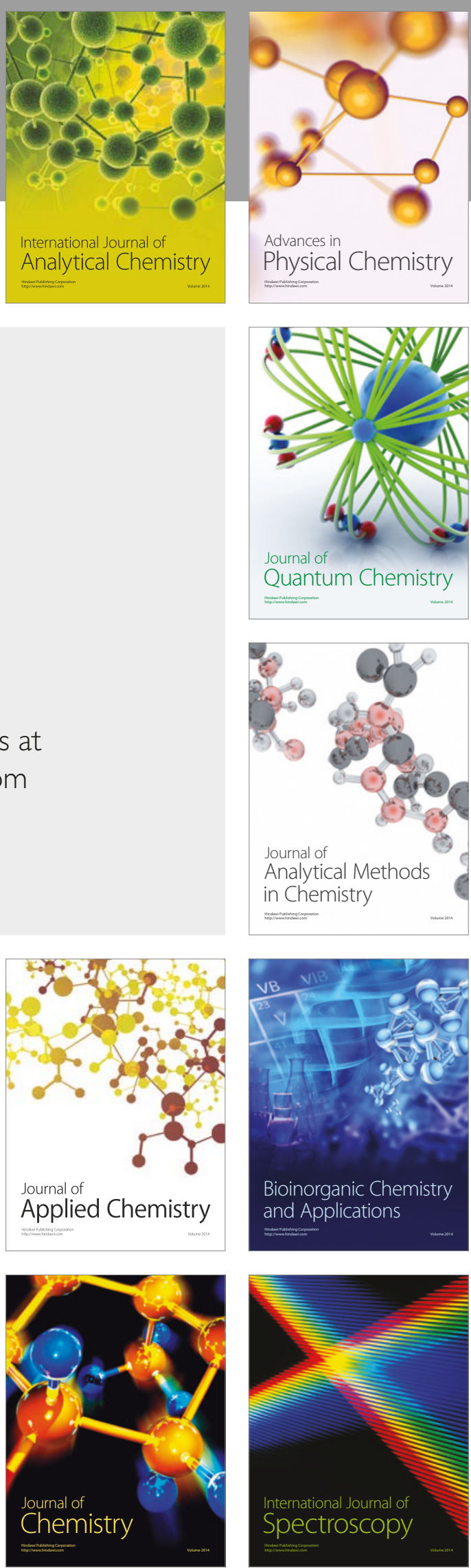